Simon Brown" / Daud Hassan

\title{
Application of the 'Precautionary Principle' in the 2000 Biosafety Protocol to the 1992 Convention on Biological Diversity
}

\section{Introduction}

The development of genetic manipulation in recent years has caused both angst and excitement. The technology has the potential to solve world hunger and create cures for many of humanities ailments. However many have also expressed concern that our understanding of the potential of the technology to cause significant environmental harm is limited. The possibility that this harm could extend beyond national boundaries has led to the technology being discussed in the international environmental law arena. The Biosafety Protocol ${ }^{1}$ is a result of nations coming together to regulate so as to minimise the potential harm and maximise the potential gains from this emerging technology.

This Article will initially detail the evolution of the precautionary principle (henceforth, 'the principle'). It will then describe the Convention on Biological Diversity ${ }^{2}$ and the Protocol 3 in parts 3 and 4. Part 5 details the application of 'the principle' in the Protocol 4 and part 6 finishes by concluding that while the Protocols could be stronger it still represents a significant step in the adoption of a precautionary approach in relation to biotechnology.

\section{The 'Precautionary Principle'}

At the basic level states have a duty not to cause serious or significant harm to other states or to common spaces. ${ }^{6}$ Linked to this obligation is the duty of states to prevent and control harm. Early in the evolution of international environmental law, questions developed as to when that duty arose in terms of forseeability, likelihood of harm and the potential gravity of the harm. ${ }^{7}$ In one of the major early international cases on the matter ${ }^{8}$ it was held that the obligation to prevent harm was only incurred if there was actual harm or serious harm which is likely to recur. Ten years later in another case it was recognised that the obligation also arose when there was a known risk to other states. ${ }^{9}$ The difficulty with the decisions was realised when states began to argue that they were not bound to take action to prevent harm unless there was clear and convincing scientific proof of actual or threat- ened harm. ${ }^{10}$ It was this concern comtined with the growing understanding that irreversible or very serious harm to the environment could orcur before the causes could be fully understood that: led to the development of what is now called the frecautionary principle.

'The principle' was first enunciated in Sivedish and German law and policy. ${ }^{11}$ shortly after that point 'the principle' began to emerge in international law. It was first adopted in the North Sea Conference $(1984)^{12}$ and then affirmed in the Berge 1 Ministerial Declaration on Sustainable Develop-ment (1990). ${ }^{13}$ Two years later it was adopted into the $1992 \mathrm{Ri}$ Declaration on Environment and Development ${ }^{14}$ and affirsned in the

* School of Law, University of New England, NSW 2351 Australia

** PhD (W'gong), LLM(Syd), Lecturer, Facnlty of Law, University of Technology, Sydney, Australia. His areas of expertise include international and comparative environmental law, law of the sea and public :nternational law.

1 The Cartagena Protocol on Biosafety to the Convention on Biological Diversity, opened for signature 29 January 2000, 39 JLM 1027, henceforth, the Protoco!.

2 Convention on Biological Diversity (Rio de Janeiro) opened for signature 5 June 1992, 31 ILM 822, (entered into force29 December 1993), henceforth, the Convention.

3 The Cartagena Protocol on Biosafety to the Convention on Biological Diversity, opened for :ignature 29 January 2000, 39 ILM 1027.

4 lbid

5 Ibid.

6 Patricia Birnie and Alan Boyle, International Law of the Environment, (22nd ed, 2002) 115.

7 Ibid

8 The Trail Smelter Arbitration (United States v Canada) [1938].

9 Corfu Channel (United Kingdom v Albania) [1949] ICJ Reports 4.

10 Birnie, above n 6, 115

11 Birnie, above n 6, 116.

12 Ibid

13 Ibid

14 United Nations Conference on Environment and Development Declaration, June 1992. Henceforth UNCED. 
Convention. 15 Since 1992 it has been affirmed and adopted in a variety of forms in a large number of international and domestic legal instruments. ${ }^{16}$

The most recognised and broadly supported17 wording of the principle (although by no means the only) is found in Principle 15 of the Rio Declaration:

In order to protect the environment, the precautionary approach shall be widely applied by states according to their capabilities. Where there are threats of serious or irreversibledamage, lack of full scientific certainty shall not be used as a reason for the postponing of cost effective measures to prevent environmental degradation. ${ }^{18}$

The basic premise of 'the principle' is to 'institutionalise caution'19 where there is risk of significant harm. This general understanding has not, however, led to a consistently worded approach being adopted in the variety of instruments, which claim to include it. Cameron and Abouchar ${ }^{20}$ detail a variety of approaches which have been undertaken domestically and internationally criticising some as weakening the approach and applauding others. Approaches discussed by Birnie go so far as to make an activity impermissible unless it can be shown that it will not cause unacceptable harm to the environment. ${ }^{21}$ This approach is probably the strongest adopted as yet because it tends to reverse the burden of proof of risk onto the 'developer'.

As a result of the widely varying approaches to 'the principle' its status in international environnental law is vexed. The courts have also been ?luctant to rely heavily on 'the principle', adding to the confusion. ${ }^{22}$ It seems likely therefore that it is involved in the long and often slow process of becoming customary international law. ${ }^{23}$ As it becomes more universally and consistently applied by states and within treaties it is more likely that it will become recognised as such by the courts.

\section{The Convention on Biological Diversity}

The Convention ${ }^{24}$ was opened for signature in 1992 as a result of the Rio Declaration. It entered into force in 1993 and by the year 2000177 countries were parties to it. As such it is one of the most widely ratified environmental treaties in the world to date. Its scope includes the conservation of biological diversity, the sustainable use of biological resources, access to genetic resources, the sharing of benefits derived from genetic material and access to biotechnology. 25

The 'principle' is dealt with in the Convention's Preamble where it is noted that

Where there is a threat of significant reduction or loss of biological diversity, lack of full scientific certainty should not be used as a reason for postponing measures to avoid or minimise such a threat. ${ }^{26}$

It has been argued that the wording of 'the principle' in the Convention ${ }^{27}$ weakens the approach taken by the UNCED, ${ }^{28}$ although it is also pointed out that the impact assessment provisions within the operational text of the Convention ${ }^{29}$ offset this weakening somewhat. $3^{30}$ The provisions do this by calling parties to introduce

Appropriate procedures requiring environmental impact assessment of its proposed projects that are likely to have significant adverse effects on biological diversity with a view to avoiding or minimising such effects and, where appropriate, allow for public participation in such procedures. ${ }^{31}$

15 Convention on Biological Diversity (Rio de Janeiro), opened for signature 5 June 1992, 31 ILM 822, (entered into force29 December 1993).

16 James Cameron and Juli Abouchar, 'The Precautionary Principle: A fundamental Principle of Law and Policy for the Protection of the Global Environment' (1991) 14 Boston College International And Comparative Law Review 1, 4-12.

17 Philippe Sands, Principles of International Environmental Law (22nd ed, 2003) 268.

18 United Nations Conference on Environment and Development Declaration, June 1992, Principle 15.

19 Cameron, above $\mathrm{n} 16,3$.

20 Ibid, 4-12.

21 Birnie, above $n$ 6, 118

22 Gabcikovo-Nagymaros (Hungary v Slovakia) [1997] IC] Reports 7 and Beef Hormones case -Measures Concerning Meat and Meat Products (Hormones) (EC) [1998] WTQ Appellate Body.

23 The process involves state practice, intermational recognition of a principle and opinio juris. This process was discussed in the North Sea Continental Shelf Cases (Federal Republic of Germany $v$ Denmark: Federal Republic of Germany v Netherlanas) [1969] IC] 3.

24 Convention on Biological Diversity (Rio de Janeiro), opened for signature 5 June 1992, 31 ILM 822, (entered into foree29 December 1993).

25 Birnie, above $\mathrm{n} 6,568$

26 Convention on Biological Diversity (Rio de Janeiro), opened for signature 5 June 1992, 31 ILM 822, (entered into force29 December 1993), Preamble.

27 Convention on Biological Diversity (Rio de Janeiro) opened for signature 5 June 1992, 31 ILM 822, (entered into force29 December 1993).

28 United Nations Conference on Environment and Development Declaration, June 1992, Principle 15.

29 Convention on Biological Diversity (Rio de Janeiro), opened for signature 5 June 1992, 31 ILM 822, (entered into forcezg December 1993).

30 Bimie, above n 6,547 and Article 1.4 Convention on Biological Diversity (Rio de Janeiro), opened for signature 5 June 1992, 31 JLM 822, (entered into force29 December 1993). 


\section{HNOTES}

Biotechnology is dealt with in Articles 16 and $19 .{ }^{32}$ Article 19 (3) calls for parties to consider the need for an international protocol to set out safe methods for the transfer of living modified organisms (LMQ' $s$ ) which 'may have an adverse effect on the conservation and sustainable use of biological diversity. ${ }^{33}$ The Biosafety Protocol 34 is a result of this Article. ${ }^{35}$

\section{The Cartagena Protocol on Biosafety}

In 1995 at the second meeting of the Conference of Parties to the Convention ${ }^{36}$ a Working Croup on Biosafety was established with the goal of developing a draft protocol. From that point on the process of negotiation was long and difficult with a number of international factions developing. (Australia sided with the Miami group which included Argentina, Canada, Chile, Uruguay and the USA). ${ }^{37}$ one of the main concerns of the Miami Group was the possibility that the wording of the Protocol $3^{8}$ would make it inconsistent with rights and obligations existent under the World Trade Organisation Agreements. ${ }^{39}$ After much debate the Protocol40 was adopted in Montreal in 2000. It has been hailed by some as providing a regulatory framework to reconcile the respective needs of trade and environmental protection with respect to the biotechnology industry. ${ }^{41}$ The objective of the Protocol is contained in Article 1 :

In accordance with the precautionary approach contained in Principle 15 of the Rio Declaration on Environment and Development, the objective of this protocol is to contribute to ensuing an adequate level of protection in the field of safe transfer, handling and use of living modified organisms resulting from modem biotechnology that may have adverse effects on the conservation and sustainable use of biological diversity, taking into account risks to human health, and specifically focussing on transboundary movements. ${ }^{42}$

'The principle' is mentioned in a number of provisions in the Protocol. As a result the Protocol has been applauded by some as the first operationalisation of the precautionary principle in the body of an international environmental agreement. 43

\section{How is the Precautionary Principle Applied in the Biosafety Protocol?}

As discussed earlier, 'the principle' is mentioned in a number of provisions within the Protocol.44 It is reaffirmed in the preamble and mentioned as part of the objective of the protocol in Article 1. It is also stated in Articles 10 (6) and $11(8)$
Lack of scientific certainty due to insufficient relevant scientific information or knowled ge regarding the extent of the potential adverse effects of an LMO on biodiversity, taking into acccunt risks to human health, shall not prevent a Party of import from taking a decision, as appropriate, with regard to the import of the LMO in question, in order to avoid or minimise such potential adverse effects. 45

The final mention of the principle is in Annex 3 which deals with risk assessment where it is said that 'Lack of scientific knowledge or scientific consensus should not necessarily be interpreted as indicating a particular level of risk, a:n absence of risk or an acceptable risk:. ${ }^{46}$

31 Article 141 (a) Convention on Biological Diversity (Rio de Janeiro), opened for signature 5 June 1992, 31 ILM 822, (entered into forcezg December 1993).

32 Articles 16 and 19 Convention on Biologgical Diversity (Rio de Janeiro), opened for signature 5 June 1992, 31 ILM 822, (entered into forcezg December 1993).

33 Article 19 (3) Convention on Biological Diversity (Rio de Janeiro), opened for signature 5 June 199)2, 31 ILM 822 (entered into force29 December 1993).

34 The Cartagena Protocol on Biosafety to the Convention on Biological Diversity, opened for signature 29 January 2000, 39 ILM 1027, henceforth, the Protocol.

35 Article 19 (3) Convention on Biological Diversity (Rio de Janeiro), opened for signature 5 June 1992, 31 IL.M 822 (entered into force29 December 1993).

36 Article 19 (3) Convention on Biological Diversity (Rio de Janeiro), opened for signature 5 June 1992, 31 ILM 822, (entered into force29 December 1993).

37 Department of Foreign Affairs and Traje, Cartagen Protocol On Biosafety - Speech - Austrc.lia 's Position (2001) Australian Covemment http:llwww.dfat.gov aulenvironmentlbsplhillmano300.html at 16 April 2004.

38 The Cartagena Protocol on Biosafety to tize Convention on Biological Diversity, opened for signature 29 January 2000, 39 ILM 1027.

39 39Agreement Establishing the World Trade Organisation, opened for signature 15 April 1994, 33 ILM 1125 (entered into force 1 January 1995).

40 The Cartagena Protocol on Biosafety to tize Convention on Biological Diversity, opened for signature 29 January 2000, 39 ILM 1027.

41 The Secretariat of the Convention on Biological Diversity, Cartagena Protocol on Biosafety to the Convention on Biological Diversity (2000) 1

42 Article 1, The Cartagena Protocol on Biosafety to the Convention on Biological Diversity, opened for signature 29 January 2000, 39 ILM 1027.

43 Heike Baullmer, 'The Cartagena Protoccil on Biosafety - Environmental Perspective's' (2001) 1\& Environmental and Planning Law Joumal 46, 52.

44 The Cartagena Protocol on Biosafety to tize Convention on Biological Diversity, opened for signature 29 January 2000, 39 ILM 1027.

45 Ibid 


\section{W}

It could be argued on this basis alone that 'the principle' is well represented in the Protocol. 47 However, the negotiation process was fraught with difficulty and the resultant application of 'the principle' is still under much debate. The confusion surrounding how strong 'the principle' is within the Protocol $4^{88}$ is as a result of provisions demanded by the Miami Toup and the EU. The Miami group was particulary concerned that trade not be disrupted and that 'the protocol be consistent with the existing international rights and obligations particularly under the World Trade Organisation'.49 On the other hand the EU and other groups (who have taken a much more cautious approach to the LMO issue) wanted strong regulation of LMO' $s$ for fear of significant environmental harm and threat to human health.50

The provisions are embodied in the preamble. 52 The Miami group requested a savings clause which states 'Emphasising that this Protocol shall not be interpreted as implying a change in the rights and obligations of a party under any existing International agreements' so as to ensure that the protocol (and the precautionary principle embodied in it) could not be used to defend protectionist trade decisions. ${ }^{22}$ On the other hand the EU pushed for the statement following the savings clause in the preamble which states 'Understanding that the above recital is not intended to subordinate this protocol to other international, agreements'.53

While both sides argue that their provision enies the other, the actual legal effect of these provisions is still uncertain. Safrin argues that in a factual situation the theoretical concerns expressed by the parties that there would be inconsistencies between the WTO Agreements54 and the Protocol55 would amount to nothing. ${ }^{56}$ She argues that in a factual situation it is likely (especially due to the calls of the Protocols' annex 3 for scientific risk assessment) that the decision making body will not allow protectionist trade measures to be taken without at least a basic scientific premise. Baumuller57 has a different opinion, arguing that the role of precautionary decision making will remain contentious due to the unresolved relationship between the Protocol and the WTO Agreements. it seems likely therefore that the strength of precautionary decision making as dictated by the Protocol $5^{8}$ will be dependant on the interpretation of the courts if and when they are called to decide upon a particular set of facts.

Two further concerns arise which suggest that the strength of 'the principle' within the Protocol59 is limited. Again, as a result of the demands of the Miami group LMO commodities intended for food, feed or fibre (as different from LMO' s intended for release into the environment) are exempt from the stringent advance informed agreement (AlA) procedure provided for by the Protocol. ${ }^{60}$ This exclusion, of itself, lacks precaution. It is clear that LMO commodities often do not differ at all from LMO's intended for release into the environment. It is also clear that the release of LMO commodities like grain could occur quite routinely in transport. It seems therefore that the most precautious approach the Protocol ${ }^{61}$ should have taken would have been the requirement for AlA on the basis of the possibility of an LMO entering the environment and causing harm, not simply on the end use of the product.

Secondly it seems that the Protocol ignores the possibility that some biotechnology has the potential to be beneficial to biodiversity values. ${ }^{62}$ Scientific assessment suggests that the potential harm is limited but that the positives are numer-

46 Annex 3, The Cartagena Protocol on Biosafety to the Convention on Biological Diversity, opened for signature 29 January 2000, 39 ILM 1027.

47 The Cartagena Protocol on Biosafety to the Convention on Biological Diversity, opened for signature 29 January 2000, 39 ILM 1027.

48 Ibid

49 Department of Foreign Affairs and Trade, above n 37

5o Sabrina Safrin, 'treaties in Collision? The Biosafety Protocol and the World Trade Organisation Agreements' (2002) 96 The American Journal of International Law 606, 610 .

51 The Preamble, The Cartagena Protocol on Biosafety to the Convention on Biological Diversity, opened for sig nature 29 lanuary 2000, 39 ILM 1027.

52 Ibid

53 Ibid

54 Agreement Establishing the World Trade Organisation opened for signature 15 April 1994, 33 ILM_1125 (entered into force 1 January 1995)

55 The Cartagena Protocol on Biosafety to the Convention on Biological Diversity, opened for signature 29 January 2000, 39 ILM 1027

56 Safrin, above $\mathrm{n}$ 50, 612 .

57 Baullmer, above n 43, 52.

58 The Cartagena Protocol on Biosafety to the Convention on Biological Diversity, opened for signature 29 January 2000, 39 ILM 1027

59 Ibid

60 Articles 8, 10 and 12, The Cartagena Protocol on Biosafety to the Convention on Biological Diversity, opened for signature 29 lanuary 2000, 39 ILM 1027.

61 The Cartagena Protocol on Biosafety to the Convention on Biological Diversity, opened for signature 29 January 2000, 39 ILM 1027

62 Jonathan Alder, 'More Sorry Than Safe: Assessing the Precautionary Principle and the Proposed International Biosafety Protocol' (2000) 35 Texas International Law Journal 173. 


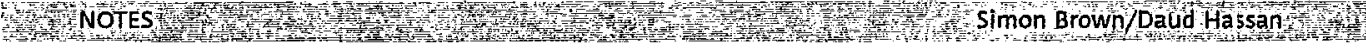

ous. ${ }^{63}$ Adler ${ }^{64}$ highlights the case of population growth andincreased food demands. There are two ways to increase food production. One is to increase agricultural land (which in turn reduces biodiversity). The second is to adopt LMO crops, which will produce more per hectare, planted. Thus saving further deforestation. It seems pertinent therefore that a precautionary approach while allowing for an assessment of the harm which could result if an organism is released into the environment should also call for an assessment of the harm that could result due to the exclusion of the technology.

\section{Conclusion}

The adoption of the precautionary principle within the operaticnal clauses of the Biosafety Protocol ${ }^{65}$ was a major step forward. It should enable states to refuse to allow LMO' $s$ to enter the environment on the basis that scientific assessment is unsure of the possible effects of such a release. However, it is clear that the statements discussed earlier in the preamble of the Protocol ${ }^{66}$ have the ability to weaken the practical application of the precautionary principle particularly in relation to the WTO Agreements. ${ }^{67}$ The ultimate strength of the Protocol ${ }^{68}$ is likely to be dependant on the interpretation of the factual situation presented to the decision making body.
While there are some concerns about the strength of the Biosafety Protocol, ${ }^{69}$ it is clear that it is an important step in the strengthening of the precautionary principle. Over time is could be a major part of the process which results in the precautionary principle being adopted as a principle of zustomary international law. This, of itself, means that the Biosafety Protocol 70 is an important and influential international instrument in relation to environmental protection.

63 Ibid, 175.

64 Ibid, 178.

65 The Cartagena Protocol on Biosafety to the Convention on Biological Diversity, opened for signature ze January 2000, 39 ILM 1027.

66 The Preamble, The Cartagena Protocol on Biosafety to the Convention on Biological Diversity, op ened for signature 29 January 2000, 39 ILM 1027.

67 Establishing the World Trade Organisation, opened for signature 15 April 1994, 33 ILM 1125 (entereil into force 1 January 1995).

68 The Cartagena Protocol on Biosafety to the Convention on Bìological Diversity, opened for signature 29 January 2000, 39 ILM 1027.

69 Ibid.

70 Ibid. 